\title{
Pengembangan Seni-Budaya sebagai Penguatan Identitas Komunitas Kejawen dan Santri di Desa pada Era Reformasi
}

\author{
Bambang Hudayana ${ }^{\mathrm{a}, 1^{*}}$ \\ a Universitas Gadjah Mada, Jalan Sosiohumaniora 3, Yogyakarta, 55281, Indonesia \\ ${ }^{1}$ bambang.hudayana@ugm.ac.id \\ * Corresponding Author
}

\begin{tabular}{l} 
INFO ARTIKEL \\
\hline Sejarah Artikel: \\
Diterima: 17 Februari 2021 \\
Direvisi: 10 Maret 2021 \\
Disetujui: 19 Maret 2021 \\
Tersedia Daring: 10 April 2021 \\
\hline
\end{tabular}

Kata Kunci:

Elite Desa

Identitas

Kejawen

Santri ABSTRAK

Politik Aliran

Artikel ini mendeskripsikan pengembangan seni-budaya sebagai penguatan identitas komunitas yang berbasis pada pilar politik aliran. Penelitian etnografi ini dilakukan di Desa Pulungsari, Bantul, secara longitudinal (2015-2019). Wawancara etnografi dilakukan kepada elite yang termasuk ke dalam golongan kejawen dan santri, pengelola pertunjukan seni-budaya, dan warga komunitas. Hasil penelitian mengungkapkan bahwa komunitas kejawen memelihara ritual, tradisi, dan perayaan desa secara Jawa melalui pementasan wayang kulit, karawitan, dan tembang macapatan yang telah menjadi identitasnya. Sementara itu, komunitas santri juga memelihara ritual, tradisi, dan perayaan hari besar agama dengan menampilkan seni-budaya keislaman seperti rodat, selawatan, dan pembacaan kitab suci Quran yang memang menjadi identitasnya. Baik komunitas kejawen maupun santri bersaing untuk memperkuat identitas masing-masing dengan cara mengembangkan festival dan kirab seni-budaya sehingga komunitas tersebut semakin tersegregasi ke dalam komunitas berbasis politik aliran. Hasil studi juga membuktikan pengembangan seni-budaya menjadi relevan bagi tokoh untuk memperkuat identitas komunitas berbasis politik aliran karena mendukung posisinya sebagai elite desa.

\section{Keywords:}

Village Elite

Identity

Kejawen

Santri

Politics of Streams

\section{ABSTRACT}

This paper chronicles the development of cultural-art performance as a way to strengthen up the community identity based on the pillars of stream politics. This ethnographic research was conducted in Pulungsari Village with a longitudinal base (2015-2019). Ethnographic interviews were conducted involving elites belonging to the kejawen and santri groups, managers of cultural-arts performances, and community members who participate in the art performances and festivals. The results of the study revealed that the kejawen community preserved Javanese rituals, traditions, and village celebrations by conducting puppet shadow, gamelan, and macapatan songs performances which then became their identity. Meanwhile, the santri community preserved Islamic rituals, traditions, and Islamic days celebrations by conducting rodat, selawatan, and reciting the great Al-Quran as their identity. Both the kejawen and santri communities compete to strengthen up their own identities by developing cultural-art festivals and processions. As a result, a community in a village was increasingly segregated into a community based on stream politics. The results of the study also prove that the development of cultural-art performances is relevant for community figures to strengthen up their identity based on stream politics because it supports their position as village elites. 


\section{Pendahuluan}

Tesis Clifford Geertz (2014) tentang politik aliran yang dibangun pada tahun 1963 berdasarkan kajian pada tahun 1950-an terus melegenda dan mempengaruhi kajian tentang dinamika politik dan agama di era Orde Baru hingga era Reformasi (Baswedan, 2004; Mukrimin, 2012; Sobari, 2016; Trihartono dan Patriadi, 2016; Burhani, 2017; Hilmy, 2018; Rubaidi, 2019). Tesis Geertz dikenal sebagai politik aliran karena ia memandang bahwa dalam masyarakat Jawa terdapat tiga kelompok sosial keagamaan, yaitu abangan, santri, dan priyayi. Masing-masing kelompok memiliki ciri-ciri sosial budaya yang unik, terutama dalam hal kelas, kepercayaan, ritual dan orientasi partai politiknya. Mereka mempunyai orientasi politik yang seseuai dengan berbagai identitas alirannya (Geertz, 2014).

Berbagai penelitian mencermati keberlanjutan tesis Geertz untuk menggambarkan struktur sosial di Jawa sepanjang masa Orde Baru hingga Reformasi. Penelitian-penelitian tersebut menggambarkan peta pergeseran kelompok aliran pada masa Orde Baru (Mukrimin, 2012; Trihartono \& Patriadi 2016), keberlangsungan aliran tersebut dalam pemilu di era Reformasi (Baswedan, 2004; Rubaidi, 2019); degenerasi dan segregasi sosial abangan dan santri serta bangkitnya identitas berwarna Islam di kalangan abangan (Mufidah, 2014; Mukodi dan Burhanuddin, 2016), serta mempertanyakan konstruksi dikotomi dengan menawarkan kejawen dan Jawa-Islam (Hilmy, 2018).

Meskipun sudah banyak studi yang membahas tentang keberlanjutan dari tesis Geertz pada masa reformasi, sedikit sekali studi yang memfokuskan perhatian pada bagaimana komunitas di desa memelihara politik aliran melalui reproduksi senibudaya seperti mengembangkan seni pertunjukan, festival dan kirab budaya. Penelitian di Desa Gumelem Banjarnegara mengungkapkan bahwa pemimpin dan warga berkepentingan memajukan senibudaya sebagai imbas dari menguatnya otonomi desa dan desentralisasi daerah (Hudayana, 2015). Penelitian di Karimunjawa juga mengungkapkan munculnya prakarsa masyarakat untuk memajukan kesenian tradisional guna mengundang masuknya wisatawan (Surojo dan Wicaksono, 2019). Penelitian lainnya menunjukkan bahwa penguatan budaya lokal juga relevan untuk menumbuhkan desa wisata (Triwardani dan Rochayanti, 2014). Tiga penelitian seni-budaya itu tidak membahas peran politik aliran dan implikasinya terhadap penguatan identitas komunitas kejawen dan santri.

Terdapat studi yang mengungkapkan hubungan antara kekuasaan dengan peningkatan kesenian tradisional berbasis pada ikatan politik aliran. Hal ini terlihat pada studi tentang meningkatnya pentas seni reog sebagai kesenian kaum abangan di Ponorogo berkaitan dengan kepentingan kekuasaan dari para elite politik (Riyadi, Mujahidin dan Tasrif, 2016). Namun demikian, studi reog tersebut tidak membahas tren dan persaingan antarkelompok aliran di desa.

Artikel ini memaparkan bagaimana komunitas kejawen dan santri di desa memperkuat politik aliran dengan cara mengembangkan seni-budaya yang menjadi identitas komunitas tersebut, dan relevansinya bagi kepentingan elite dalam memasuki pesta demokrasi di desa. Warga komunitas berkepentingan memiliki 
identitas alirannya terpelihara dan bahkan menguat, sedangkan elite bisa mencitrakan diri sebagai patron dengan menjadi sponsor bagi terpeliharanya seni-budaya yang menjadi identitas komunitasnya.

Artikel ini memandang bahwa kelompok kejawen dan santri merupakan pilar struktur sosial di pedesaan Jawa (Beatty, 2010). Kelompok kejawen mengidentifikasi dirinya sebagai penganut ajaran Islam moderat, tetapi juga menghayati ajaran Jawa yang bersumber dari agama Hindu dan kepercayaan lokal, dan cenderung melestarikan dan tradisi senibudaya Jawa. Kelompok santri adalah golongan muslim yang taat, berkomunitas dengan kyai dan memilih seni-budaya Islami. Dengan demikian, dalam hal orientasi agama, aliran yang digambarkan dalam penelitian ini bersifat dikotomi, yaitu kejawen dan santri, sehingga berbeda dengan aliran yang digambarkan dalam tesis Geertz yang memaparkan ke dalam trikotomi. Trikotomi ini menempatkan priyayi sebagai golongan menengah ke atas yang menjadi penganut ilmu kebatinan, abangan sebagai petani dan golongan bawah yang menjadi penganut sinkritisme Islam dan Hindu, dan santri yang mengindentifkasi dirinya sebagai muslim yang taat (Geertz, 2014).

Dengan menyimak dua kelompok kejawen dan santri itu, artikel ini akan menjawab dua pertanyaan, yaitu bagaimana komunitas kejawen dan santri memelihara politik aliran melalui pengembangan senibudaya yang menjadi identitasnya dan bagaimana relevansi penguatan politik aliran berbasis pengembangan seni-budaya bagi elite desa dalam pesta demokrasi. Pertanyaan penelitian tersebut dikaji di Desa Pulungsari, Daerah Istimewa Yogyakarta.

Artikel ini berbeda dengan penelitian yang dilakukan penulis di Desa Pulungsari pada tahun 2011 yang memandang bahwa kekuatan elite yang relevan dalam pesta demokrasi, yaitu strategi persuasi dan transaksional yang disebut dengan istilah lokal dengan nama glembuk (Hudayana, 2011). Dengan memakai glembuk, elite bisa mendapatkan pengaruh dengan cara memberikan janji politik dalam bentuk bantuan, uang, atau program (Hudayana, 2011). Namun demikian, dengan memakai politik aliran dan memfokuskan pada gejala seni-budaya pada lima tahun terakhir (20152019), artikel ini melihat bahwa elite akan mendapatkan pengaruh dari komunitasnya jika menjalankan peran yang relevan sebagai bagian dari identitas alirannya.

Politik aliran sebagai pengelompokan warga komunitas berbasis pada orientasi sosial-keagamaan ada karena masingmasing kelompok memelihara identitasnya sebagai kekayaan yang bernilai dalam kehidupannya (Subair, 2011; Mukrimin, 2012; Mukodi dan Burhanuddin, 2016). Kekayaan tersebut bisa berupa seni-budaya yang berfungsi sebagai alat untuk menampung pengetahuan, jagad pandang, dan orientasi nilai pada kelompok masyarakat. Dengan demikian, karena bernilai penting, maka identitas cenderung dipelihara dan dikembangkan oleh warga yang terbelah ke dalam politik aliran.

Oleh karena seni-budaya lekat dengan politik aliran, maka orang kejawen sangat berkepentingan untuk menjadi penghayat dan melestarikan seni-budaya Jawa, sedangkan orang santri pada seni-budaya Islami. Jagad pandang orang kejawen dibangun dengan menghayati berbagai ajaran hidup yang diajarkan oleh senibudaya yang menjadi identitasnya, misalnya wayang kulit, karawitan, dan tembangtembang Jawa klasik. Sebaliknya dengan santri yang memiliki jagad pandang yang dibangun dari seni-budaya seperti seni pertunjukan, festival dan kirab budaya Islami. Dengan berperan dalam pelestarian seni-budaya tersebut, elite desa bisa memelihara identitas komunitasnya dan memperoleh apresiasi dari warga komunitas yang sealiran dengannya.

Dengan memakai pendekatan prosesual dalam antropologi politik, artikel ini memandang bahwa politik di masyarakat berlangsung secara dinamis karena terjadi kontestasi antaraktor (Kurtz, 2001). Di desa setiap kelompok politik aliran berlomba 
untuk memperkuat ikatan alirannya. Salah satu cara yang dilakukan adalah mengembangkan seni-budaya yang menjadi identitasnya. Kontestasi mengembangkan seni-budaya digerakkan oleh elite. Hal ini karena mereka memiliki sumber daya untuk memobilisasi kekuatan dan kepentingan untuk memanfaatkannya (Aspinall dan Rohman, 2017).

Secara teoretis, era Reformasi telah menghadirkan kebebasan berekspresi yang membuka peluang bagi elite desa bersaing di berbagai arena politik (Antlöv, 2010). Demokratisasi desa sebagai bagian dari era Reformasi politik 1998 ikut memberikan kesempatan bagi masyarakat desa untuk mengekspresikan identitas yang bersumber dari politik aliran. Artikel ini memandang bahwa kelompok kejawen dan santri justru meningkatan politik identitas dengan cara memperkuat identitas seni-budayanya. Politik identitas menjadi alasan mengapa politik aliran tetap bertahan di masyarakat desa (Subair, 2011; Mukrimin, 2012; Mukodi dan Burhanuddin, 2016).

\section{Metode}

Penelitian ini dilakukan di Desa Pulungsari Kecamatan Imogiri Kabupaten Bantul Daerah Istimewa Yogyakarta. Sebelumnya, peneliti telah melakukan penelitian di wilayah ini (Hudayana, 2011). Pada tahun 2015-2019 peneliti sering ke Desa Pulungsari untuk melakukan penelitian dengan tema hubungan antara politik aliran dengan reproduksi seni-budaya. Peneliti menggunakan data yang dihimpun melalui hubungan sosial yang baik antara peneliti dengan elite dan warga desa. Hubungan yang baik membuat peneliti sering diundang untuk hadir dalam berbagai pentas senibudaya di desa. Peneliti dapat melakukan observasi partisipan tentang fungsi pentas seni-budaya dan juga melakukan wawancara mendalam dengan para informan, yaitu orang yang menceritakan tentang tema kebudayaan kelompoknya, dan menggunakan jagad pandang (worldview) kelompoknya (Spradley, 2016).
Informan meliputi delapan orang elite desa, terdiri atas empat elite dari kalangan elite kejawen dan empat dari kalangan santri yang menjadi aktor penting dalam pengembangan seni-budaya. Informan juga meliputi elite desa dengan status sebagai pamong, yaitu tiga orang kepala yang masuk kategori elite kejawen, dua orang kepala elite santri, dan dua orang pamong kantor desa. Informan yang lain meliputi lima orang praktisi seni-budaya kejawen dan dua orang praktisi seni-budaya santri, serta masingmasing lima orang warga dari golongan kejawen dan santri.

Data wawancara yang dikumpulkan meliputi berbagai bentuk pelestarian senibudaya dalam jangka panjang (longitudinal) yaitu selama tahun 2015-2019. Data tersebut dapat menggambarkan proses pengembangan seni-budaya dan relevansinya bagi peguatan identitas komunitas berbasis politik aliran dan agenda politik di desa, yaitu pemilhan kepala daerah (Pilkada) tahun 2015 dan pemilihan kepala desa (Pilkades) tahun 2016 dan tahun 2018.

Data kualitatif dianalisis menggunakan metode etnografi. Analisis diarahkan menemukan berbagai tema budaya yang menjelaskan tentang fungsi dari berbagai aktivitas pengembangan pentas seni-budaya, khususnya fungsi politik bagi para elite desa. Analisis fungsi politik memperhatikan sudut pandang kejawen dan santri maupun teori politik mengenai kepentingan politik dari relevansi pengembangan seni-budaya terhadap upaya mendapatkan pengaruh dalam Pilkada dan Pilkades.

\section{Hasil dan Pembahasan}

\subsection{Komunitas Kejawen dan Santri di Desa}

Desa Pulungsari pada awalnya merupakan desa pertanian, namun lambat laun karena tekanan kepadatan penduduk yang tinggi, dan industrialisasi, mereka beralih ke ekonomi non-pertanian. Transisi ini terjadi pada awal tahun 1970-an, dan pada 2019 hampir 85 persen penduduk bekerja di sektor nonpertanian. Pada 2019, jumlah penduduk desa mencapai 17.545 jiwa. Sekitar 10.500 orang bekerja di berbagai sektor, termasuk 
kerajinan tangan, perdagangan, pemerintahan, pendidikan, jasa, dan hanya sedikit yang bertahan di sektor pertanian.

Pulungsari memiliki badan pemerintahan desa yang dipimpin oleh seorang kepala desa dengan 30 perangkat desa, dan Badan Perwakilan Desa (BPD) yang beranggotakan 13 orang. Desa ini juga memiliki empat perdukuhan (sub-village) dengan setiap perdukuhan terdiri dari 3-5 dusun. Masingmasing perdukuhan mewakili suatu komunitas berdasarkan aliran dominan tertentu, meskipun masih terdapat aliran yang berbeda sebagai kelompok minoritas di dalam dukuhnya. Umumnya orang kejawen tinggal di wilayah Perdukuhan Pucung dan Jimatan, sedangkan orang santri di Perdukuhan Girigondo. Dua kelompok itu juga menempati wilayah perdukuhan Singosaren secara seimbang (lihat Tabel 1). Karena mengelompok dalam satu perdukuhan atau jumlahnya relatif seimbang, maka komunitas kejawen dan santri itu bisa memelihara tradisi keagamaan dan seni-budaya yang menjadi identitasnya.

Tabel 1. Distribusi komunitas Kejawen dan Santri di

\begin{tabular}{|c|c|c|c|}
\hline \multicolumn{4}{|c|}{ Desa Pulungsari } \\
\hline No. & $\begin{array}{c}\text { Orientasi } \\
\text { Politik } \\
\text { Aliran }\end{array}$ & $\begin{array}{c}\text { Nama } \\
\text { Padukuhan } \\
\text { (Sub- } \\
\text { village) }\end{array}$ & $\begin{array}{l}\text { Nama Dusun } \\
\text { (Hamlet) }\end{array}$ \\
\hline \multirow[t]{2}{*}{1.} & Kejawen & Pucung & $\begin{array}{c}\text { Dengkeng, } \\
\text { Nogosari I } \\
\text { Nogosari II, } \\
\text { Jatirejo, } \\
\text { Karangasem, } \\
\text { Karangtalun }\end{array}$ \\
\hline & & Jimatan & $\begin{array}{l}\text { Kedungbuweng, } \\
\text { Jimatan, } \\
\text { Tilaman } \\
\end{array}$ \\
\hline 2. & Santri & Girigondo & $\begin{array}{c}\text { Giriloyo, } \\
\text { Cengkehan } \\
\text { Karangkulon } \\
\end{array}$ \\
\hline 3. & $\begin{array}{c}\text { Campuran } \\
\text { Santri dan } \\
\text { kejawen }\end{array}$ & Singosaren & $\begin{array}{c}\text { Singosari, } \\
\text { Manggung and } \\
\text { Bendo }\end{array}$ \\
\hline
\end{tabular}

Di Pulungsari, kelompok kejawen mengklaim bahwa mereka sebenarnya memeluk agama Islam, tetapi bukan seperti orang santri. Bagi orang kejawen beragama Islam tidak harus meninggalkan seni-budaya
Jawa, dan tidak harus fanatik sehingga cenderung bergaul dengan sesama santri secara eksklusif. Bagi mereka, masjid adalah tempat ibadah salat jumat, dan aktivitas keagamaan di komunitas lebih baik dilakukan di forum rukun tetangga dan dusun. Berbeda dengan orang kejawen, orang santri memang lebih taat, disiplin dan rajin melakukan salat dan menjadikan masjid sebagai arena untuk bergaul dengan sesama santri. Mereka menempatkan para kyai dan ustad sebagai tokoh panutan dan ikut perkumpulan Nahdlatul 'Ulama (NU), terutama untuk kegiatan pengajian dan kegiatan sosial-keagamaan.

Orang kejawen mempunyai pandangan yang kuat tentang pentingnya memelihara seni-budaya Jawa sebagai identitasnya. Bagi mereka, seni-budaya Jawa seperti bahasa, ketoprak, wayang kulit, pakaian batik, dan berbagai adat istiadat lokal merupakan kekayaan orang Jawa yang sangat bernilai, karena mengandung ajaran luhur sehingga bisa hidup beradab, bertingkah laku halus, sopan dan santun, toleran, dan rukun dengan sesama. Bagi mereka menjadi muslim tidak berarti harus meninggalkan seni-budaya Jawa yang menjadi kebanggaan dan identitas orang Jawa. Sebaliknya, santri memandang bahwa mereka harus menjadi soleh dan meninggalkan seni-budaya yang tidak Islami, atau membuat seni-budaya yang diislamkan sesuai dengan tradisi Islam dari ajaran Nahdlatul 'Ulama (NU).

Dalam agama Jawa, semua aliran, khususnya abangan mempunyai tradisi menyelenggarakan selamatan (Geertz, 2014). Selamatan dapat diartikan sebagai ritual bersama komunitas atas peristiwa-peristiwa penting yang dialami oleh warga komunitas dalam hidupnya (Geertz, 2014; Boogert, 2017).

Penelitian ini menemukan bahwa selamatan juga dilakukan oleh kejawen dan santri. Perbedaan antara kedua kelompok tersebut terletak pada fungsi selamatan sebagai bagian dari identitas. Selamatan bagi orang kejawen berfungsi untuk memperkuat solidaritas di antara masyarakat, sedangkan santri untuk memperbanyak penghayatan 
dan praktik keimanan dan amalan dalam beragama sehingga selamatan yang biasanya diisi dengan tausiah (khotbah formal) dan mengaji. Selain itu banyak istilah selamatan telah diganti dengan istilah yang lebih islami, seperti tasyakuran dan menggunakan istilah Arab untuk menyebut beberapa jenis syukuran seperti aqiqah untuk kelahiran anak.

Dari segi pilihan partai politik dan ormas, orang kejawen cenderung mengikuti partai yang berkuasa. Pada masa Orde Baru, elite kejawen adalah konstituen partai Golkar dan sebagian kecil menjadi konstituen Partai Demokrasi Indonesia (PDI). Pada era Reformasi, orang kejawen cenderung memilih Partai Demokrasi Indonesia Perjuangan (PDIP). Banyak elite kejawen juga bergabung dengan organisasi profesi. Sebaliknya, santri merupakan konstituen dari partai Islam, yaitu Partai Persatuan Pembangunan (PPP) pada masa Orde Baru, tetapi sebagian besar kemudian bergabung dengan Partai Kebangkitan Bangsa (PKB) pada masa Reformasi. Santri juga berbeda dengan kejawen karena umumnya menjadi anggota perkumpulan organisasi NU dan tarekat yang dipimpin oleh para kyai di desa.

\subsection{Elite Kejawen dan Elite Santri di Desa Pulungsari}

Aktor yang berperan penting dalam pelestarian seni-budaya adalah para elite desa yang diikenal tokoh masyarakat. Hudayana (2011) telah memetakan stratifikasi elite di Desa Pulungsari. Melalui artikel ini pemetaan dikembangkan untuk membedakan elite kejawen versus santri. Tabel 2 mencatat stratifikasi elite berbasis pada politik aliran yang terdiri dari golongan teratas sampai bawah. Mereka meliputi kyai, pamong desa, dan pengusaha kelas menengah ke atas, pegawai negeri sipil, tentara, polisi dan guru di desa. Tabel 2 menggambarkan bahwa elite desa didominasi oleh golongan kejawen. Hal ini karena sebagian padukuhan di Pulungsari merupakan komunitas kejawen, dan secara tradisional elite kejawen merupakan penguasa pemerintahan desa.
Tabel 2. Distributsi Eli Desa Menurut Posisinya dalam Politik Aliran di Desa Pulungsari, 2019

\begin{tabular}{|c|c|c|c|}
\hline No. & $\begin{array}{c}\text { Strata dan } \\
\text { kategori elite }\end{array}$ & $\begin{array}{c}\text { Jumlah dan } \\
\text { Persentasi } \\
\text { Elite } \\
\text { Kejawen }\end{array}$ & $\begin{array}{c}\text { Jumlah } \\
\text { dan } \\
\text { Presentase } \\
\text { Elite } \\
\text { Santri } \\
\end{array}$ \\
\hline 1. & Kyai & - & $\begin{array}{c}6(25,00 \\
\%)\end{array}$ \\
\hline 2. & Pamong desa & $25(50,00 \%)$ & $\begin{array}{c}5(20,83 \\
\%)\end{array}$ \\
\hline 3. & Politisi & $11(22,00 \%)$ & $5(20,83 \%$ \\
\hline 4. & Pengusaha & $12(24,00 \%)$ & $\begin{array}{c}4(16,67 \\
\%)\end{array}$ \\
\hline 5. & $\begin{array}{c}\text { ASN, TNI, } \\
\text { Tentara dan } \\
\text { guru }\end{array}$ & $8(16,00 \%)$ & $\begin{array}{c}4(16,67 \\
\%)\end{array}$ \\
\hline & Total & $50(100,0 \%)$ & $24(100 \%)$ \\
\hline
\end{tabular}

Sebaliknya, sedikit elite desa dari kalangan santri yang menduduki jabatan sebagai pamong. Santri yang dapat menjadi pamong terutama kedudukannya sebagai kepala dusun dan menjabat kepala dusun di komunitas santri. Komunitas kejawen tetap dikuasai elite kejawen, dan sebaliknya pada komunitas santri, sehingga akses mereka untuk mendapatkan pengaruh berbasis pada ikatan politik aliran.

Elite-elite desa juga mempunyai kecenderungan menjalankan fungsi untuk memelihara komunitas alirannya. Kyai adalah tokoh pemimpin informal terkuat di dalam desa dan lintas desa. Mereka dihormati santri dan para elite desa karena karisma, dan pengaruh politiknya di hadapan para politisi di tingkat daerah sampai desa. Fungsi kyai memelihara aliran tampak pada aktivitasnya dalam memimpin umat, upacara, dan menjaga tradisi komunitas Islam. Kyai juga menjadi patron bagi para politisi PKB dan PPP di Bantul dan pamong dari komunitas santri.

Strata elite kedua adalah pamong desa. Mereka menjalankan peran sebagai pejabat pemerintah desa. Mereka juga ikut memelihara politik aliran dengan memfasilitasi dusun dan desanya menyelenggarakan pentas seni-budaya Jawa, misalnya wayang kulit, ketoprak, dan kuda lumping, sedangkan elite santri 
menyelenggarakan acara pengajian akbar, haul kyai Marzuki, takbir keliling, dan lomba anak soleh.

Kelompok ketiga elite desa adalah politisi yang berpengaruh di Pulungsari. Ada yang berhasil seperti elite santri yang menjadi wakil kepala daerah dan dua elite santri lainnya serta dua elite kejawen yang menjadi anggota DPRD Bantul. Para politisi sering tampil sebagai donatur dalam acara sosial-budaya dan memanfaatkan acara itu untuk mempopulerkan namanya dan menyebarkan agenda politiknya.

Kelompok elite desa keempat adalah para pelaku usaha yang bergerak di bidang kerajinan tangan, jasa konstruksi, dan perdagangan burung penyanyi. Kelompok elite kelima adalah 11 dari 420 orang yang merupakan PNS, polisi, atau guru yang sebagian besar bekerja di luar desa. Selain kyai, semua politikus, elite pengusaha, PNS, dan guru biasanya aktif di organisasi massa, dan saling bersaing melalui mekanisme demokrasi untuk memperebutkan posisi sebagai kepala desa (Aspinall dan Rohman, 2017).

Artikel ini mengamati sejumlah elite kejawen dan santri yang secara nyata berperan dalam pengembangan seni-budaya. Peran para elite adalah menjadi pelindung berbagai bentuk dan aktivitas seni-budaya. Elite yang mengorganisasi pentas senibudaya biasanya berada di pundak kyai, kepala desa, dan kepala dusun. Dalam menjalankan aktivitasnya, mereka dibantu para kepala Rukun Tetangga (RT) dan ketua perkumpulan kesenian, guru dan ustaz. Para ketua RT biasanya mengajak warga untuk ikut menjadi penonton, pemain, atau panitia. Selain itu juga berpartisipasi memberikan iuran untuk pendanaan upacara dan pentas seni-budaya di dusunnya.

\subsection{Pengembangan Seni-budaya Jawa dalam komunitas Kejawen}

Jumlah komunitas kejawen yang mencapai dua kali lipat daripada komunitas santri membuat komunitas kejawen lebih dominan di Desa Pulungsari. Dominasi itu ditampilkan dengan baik secara politik maupun kultural. Secara politik, elite politik di desa didominasi oleh elite kejawen, secara kultural komunitas kejawen menjadikan seni-budaya kejawen sebagai representasi dari seni-budaya desa. Seni-budaya kejawen itu adalah pagelaran wayang kulit, ketoprak, kuda lumping, karawitan, macapatan, dan festival lomba makanan tradisional, pakaian adat dan budi-pekerti luhur.

Setiap tahun, dua pedusunan kejawen yaitu Padukuhan Pucung dan Jimatan selalu menyelenggarakan upacara bersih padukuhan. Puncak perayaan diisi dengan pagelaran wayang kulit yang diiringi suara gamelan dan sinden yang melantunkan tembang Jawa. Hajatan perayaan bersih padukuhan dipimpin oleh para kepala dusun dan diselenggarakan oleh seluruh kepala keluarga. Hajatan pentas seni-budaya itu menjadi sebuah agenda rutin untuk melestarikan dan mengukuhkan identitas kejawen.

Setiap tahun, misalnya lima kepala dusun di pedukuhan Pucung bekerja sama untuk menyusun kepanitiaan dan menentukan dusun mana yang secara bergiliran menjadi tuan rumah hajatan bersih dusun. Mereka juga bersama panitia memilih dalang dan grup karawitan serta sinden yang disewa untuk mengisi puncak perayaan bersih dusun. Selain itu, mereka bersama panitia menentukan besarnya iuran per-warga. Semua warga santri yang merupakan kelompok minoritas di dalam padusunan Puncung wajib ikut memberikan iuran. Untuk menenuhi kebutuhan anggaran, elite di Padukuhan Pucung memberikan bantuan yang besarnya berkisar Rp 200.000 sampai Rp 1.000.000 per orang. Donasi ini sebagai bagian dari unjuk muka elite untuk memberikan kepedulian terhadap hajatan warga.

Di tingkat desa, pemerintah desa di bawah para kepala desa dan 18 pamong yang umumnya orang kejawen selalu terobsesi 
untuk mementaskan wayang kulit sebagai rangkaian kegiatan peringatan hari jadi Desa Pulungsari. Dana hajatan diambilkan dari dana milik desa ditambah dengan donasi dari para elite. Kepala desa, para pamong dan para elit politik memberikan donasi sebagai bagian dari kewajiban sosial mereka sebagai pemimpin masyarakat.

Selama lima tahun (2015-2019) para elite desa kejawen dari kalangan pamong dan pengusaha berhasil dalam mengembangkan penyelenggaraan senibudaya Jawa karena memiliki solidaritas dan gotong-royong. Pengembangan itu antara lain meningkatkan kegiatan perkumpulan karawitan, membangun sanggar kesenian Jawa, dan mementaskan wayang kulit di luar acara peringatan bersih padukuhan, dan hari kelahiran desa, mementaskan wayang kulit di padukuhan santri, membuat berbagai bersih dusun selain mempertahankan bersih padukuhan di Pucung dan Jimatan, dan terutama menyelenggarakan berbagai pawai dan festival seni-budaya Jawa di tingkat dusun dan desa.

Perkumpulan karawitan desa dengan nama Bayu Swara telah terbentuk sejak tahun 2013. Kepala Desa Bayu dan bersama dengan para pamong berhasil membujuk seorang warga yang kaya agar mewariskan perangkat gamelan kepada masyarakat desa. Pada tahun 2015, para seniman mulai rutin melatih para pamong dan warga untuk belajar menjadi penabuh gamelan.

Pada tahun 2016-2017 empat orang elite kejawen memugar rumah joglo dan limasan, dan dua di antara mereka memanfaatkannya untuk sanggar seni dan karawitan. Sanggar ini menjadi arena bagi warga Dusun Karangasem untuk belajar karawitan. Riyadi, pemilik sanggar bersama dengan elite desa juga membangun sanggar kerajinan kulit yang memperkuat posisi Desa Pulungsari sebagai produsen kerajinan wayang kulit.
Kepala desa dan para pecinta senibudaya Jawa juga mencari peluang untuk mendapatkan dukungan dan donasi dari lembaga sosial dan perusahaan swasta guna melakukan pengabdian pada masyarakat dan mementaskan wayang kulit di desa. Salah satu acaranya adalah sunatan massal yang dimeriahkan dengan pentas wayang kulit. Pada tahun 2016 para penghayat kejawen di Yogyakarta juga mensponsori pentas wayang kulit di desa. Kepala desa dan pamong kejawen berhasil membujuk kyai di Girigondo agar bersedia menggelar wayang kulit di dukuhnya. Mereka memandang bahwa wayang kulit telah diislamkan sehingga tidak bisa didiskreditkan sebagai kesenian yang sesat. Wayang kulit memang merupakan warisan budaya Jawa yang telah diislamkan oleh para wali penyebar agama Islam di Jawa (Suhardjono, 2016; Nasif dan Wilujeng, 2018)

Sebelumnya, para kyai melarang pertunjukan wayang kulit di dukuhnya karena dianggap kurang Islami. Namun, kyai secara mengejutkan menerima tawaran dari kepala desa untuk mementaskan wayang kulit tahun 2016. Sikap akomodatif kyai merupakan sebuah strategi kaum santri untuk membangun harmoni sosial di desa (Riyadi, Mujahidin, dan Tasrif, 2016). Kyai tidak mau konflik dengan kaum kejawen, dan mereka mempunyai kepentingan sama, yaitu menolak atas semakin maraknya pentas musik pop dan dangdut yang dinilai bertentangan dengan budaya Jawa dan Islam. Penyanyi dangdut koplo umumnya menampilkan gerakan tarian yang berpakaian seksi. Ancaman terhadap senibudaya tradisional menjadi gejala yang menonjol di desa karena meningkatnya arus teknologi komodifikasi digital (Irianto, 2017).

Mekipun sudah merasa mampu melestarikan seni-budaya, elite desa dan komunitas kejawen merasa bahwa zaman terus berubah karena semakin sedikit warga 
yang menonton pentas wayang kulit. Gagasan untuk melestarikan kesenian ini muncul di kalangan para ahli kesenian seperti memperkenalkan wayang yang sesuai dengan usia, seperti wayang untuk anak-anak atau pemula (Junaidi, Suseno dan Aziz, 2018). Kepala Desa Bayu pernah memperkenalkan wayang untuk gamelan dan wayang untuk dakwah agar banyak orang mau menonton. Namun minat orang menonton wayang terus menurun. Hal ini dibuktikan dengan minimnya jumlah penonton wayang kulit di Pendopo Desa Pulungsari pada awal tahun 2017. Mereka memandang bahwa orang Jawa akan kehilangan identitasnya manakala mereka melupakan wayang kulit dan gamelan yang merupakan warisan bangsa dan memiliki cita rasa seni yang tinggi.

Selain mendorong komunitas santri mau mementaskan seni-budaya Jawa, para elite kejawen membuat kirab budaya dalam setiap acara bersih dusun. Gagasan kirab budaya ini mengikuti keberhasilan FORCIBB (Forum Cinta Budaya Bangsa) di Kecamatan Imogiri yang berhasil membuat kirab budaya tahunan di tingkat kecamatan sehingga banyak orang datang menonton dan mengapresiasinya. Pengembangan senibudaya melalui festival dan kirab berdampak pada meningkatnya penonton dan arus wisatawan yang masuk ke desa (Hudayana, 2015, Schlehe, 2017; Surojo, dan Wicaksono, 2019).

Mulai tahun 2018, komunitaskomunitas kejawen di Padukuhan Pucung, Jimatan dan di Dukuh Bendo di wilayah Padukuhan Singosaren menyelenggarakan festival seni-budaya Jawa. Gagasan mengadakan festival ini muncul karena acara ini dipercaya mampu membuat banyak pemuda untuk peduli dan bangga sebagai orang Jawa. Hal ini karena seni-budaya Jawa dapat mengikuti zaman, seperti misalnya pakaian batik dan makanan tradisional yang semakin diapresiasi masyarakat luas dan turis di Yogyakarta. Menggelar acara kesenian tradisional ditujukan untuk menumbuhkan kecintaan masyarakat terhadap kebudayaan Jawa (Irhandayaningsih, 2018).

Mula-mula festival diselenggarakan untuk melengkapi upacara dan perayaan bersih dusun. Misalnya dalam perayaan bersih Padukuhan Pucung tahun 2018 dan 2019, semua peserta upacara memakai pakaian adat Jawa. Upacara diisi dengan pagelaran wayang kulit, ziarah bersama para wakil warga ke makam leluhur, dan kirab budaya untuk mementaskan perjalanan para leluhurnya dalam membangun wilayah dan kesejahteraan bersama. Acara festival budaya mewarnai perayaan bersih perdukuhan, yang diisi dengan pentas warga berpakaian adat, pesta makan tradisional dengan alunan musik gamelan, tembang Jawa, serta diperkaya dengan tari-tarian Jawa.

Festival seni-budaya di Perdukuhan Pucung membuat banyak warga dari kalangan kejawen kemudian menyukainya. Mereka sering melihat di media TV atau media sosial bahwa festival seni-budaya Jawa sedang menjadi tren di berbagai desa. Mereka terpesona kembali dengan kekayaan budaya Jawa yang bisa menjadi pusat perhatian publik. Seorang informan mengatakan "Festival dan kirab budaya dihadirkan agar orang suka menonton karena sudah enggan menonton wayang semalam suntuk. Mereka suka menonton orang yang menari, menyanyi, melawak dan pawai dengan pakaian adat dan nuasa Jawanya". Dengan kata lain, informan menunjukkan pelestarian seni-budaya Jawa harus menjadi tontonan dan hiburan yang popular di masyarakat. Pandangannya itu berlawanan dengan temuan studi yang memandang bahwa pelestarian festival merupakan ajang untuk membuat senibudaya Jawa bisa lebih diterima publik khususnya dari kalangan muslim santri 
(Schlehe, 2017). Festival seperti kirab budaya penting bagi masyarakat Jawa masa kini karena hanya dengan cara seperti itu revitalisasi budaya Jawa dapat dilakukan dengan cara mempromosikan ritual menjadi upacara dan hiburan yang menarik wisatawan (Schlehe, 2017).

Kalau tidak menyelenggarakan kirab budaya, dusun yang kuat komunitas kejawennya cenderung menyelenggarakan festival dan malam kesenian dan diiringi dengan tari-tarian jawa. Dalam festival itu, mereka menyelenggarakan lomba makanan tradisional, pakaian adat, dan penguasaan budaya Jawa. Tren festival budaya Jawa menjadi fenomena baru di Pulungsari dan sekitarnya. Dalam memeriahkan hari besar seperti Hari Kemerdekaan dan Sumpah Pemuda, Kartini, hari lahir Desa Pulungsari, tampil kegiatan seperti lomba busana Jawa, berpidato dengan memakai bahasa Jawa, serta mengenal berbagai tata karma dan adat upacara. Acara itu dipercaya mampu meningkatkan kesadaran warga bersama bahwa orang desa sudah selayaknya bangga dan suka memajukan budaya Jawa.

\subsection{Pengembangan Seni-budaya Islami dalam Komunitas Santri}

Tokoh kreator dan pelestari seni budaya Islami di Desa Pulungsari adalah para kyai. Para Kyai sadar bahwa mereka perlu berdakwah dengan menghadirkan tradisi yang lebih Islami. Wayang kulit menjadi media dakwah yang dikembangkan oleh para wali penyebar agama Islam (Nasif dan Wilujeng, 2018). Namun demikian, para Kyai di Pulungsari memandang bahwa santri perlu memiliki seni-budaya yang lebih menampilkan doa, tembang, dan berbagai citra keislaman. Oleh karena itu, para Kyai dan santri tidak pernah menyelenggarakan pagelaran wayang kulit, dan tembang Jawa di wilayahnya. Sebaliknya, mereka lebih menyukai berbagai seni-budaya Islami seperti rodat dan salawatan. Para santri suka merayakan peringatan hari jadi pesantren, haul wafatnya kyai, dan maulud nabi dengan menampilkan ritual dan kesenian Islami seperti pengajian, selawatan dan bermain rodat serta memainkan rebana.

Kyai Marzuki mengawali pengembangan seni-budaya Islami di Desa Pulungsari. Ia mengganti upacara wiwit, yaitu pesta dan perayaan pasca panen yang sangat kejawen menjadi majemukan yang sangat Islami. Disebut sangat kejawen karena upacara itu merupakan sinkretisme kepercayaan Hindu dan Islam. Kyai kemudian dengan arif memodifikasi ritual kejawen menjadi ritual Islam (Fauzi, 2012). Majemukan mirip dengan banyak ritual lain di Jawa yang telah diwarnai dengan muatan nilai Islami (Kholil, 2011; Jamil, 2013; Arinda dan Yani, 2014).

Kyai Marzuki mulai melembagakan majemukan sebagai pengganti upacara wiwit pada tahun 1950-an. Senada dengan NU, Marzuki mengandalkan reproduksi kearifan lokal untuk dakwah dan mengembangkan komunitas santri (Arifin, 2008). Wiwit merupakan salah satu contoh kearifan lokal yang tertanam dengan semangat syukur dan berbagi rezeki setelah panen, yang kemudian diubah Marzuki menjadi ritual Islam. Dia memodifikasi ritual wiwit ini dengan menggunakan nama majemukan yang berarti keragaman rezeki yang diberikan oleh Allah. Agar upacara menjadi Islami, Kyai menghapus prosesi sesaji terhadap Dewi Sri dan menggantinya dengan doa syukur atas hasil panen yang dipentaskan dalam bentuk gunungan, mirip dengan gunungan dalam upacara Sultan Yogyakarta (sekaten). Para santri mengarak gunungan yang diiringi dengan mementaskan rebana sebagai instrumen untuk mengiringi tembang pujian kepada Allah. Mereka berbaris membawa gunungan dari masjid di pesantren ke pendopo Dusun Karangkulon kemudian dilanjutkan ke Masjid di Dusun Cengkehan yang diyakini sebagai tempat sultan dan kyai mengembangkan tradisi budaya Islam. 
Tradisi ritual Islam Jawa memang diwarnai oleh pandangan mistis tentang hadirnya kyai dan masjid sebagai pusat penyebaran agama Islam (Rubaidi, 2019).

Dalam upacara majemukan, semua warga santri berpartisipasi aktif. Mereka menjadi panitia, menyediakan tenaga, dana selamatan dan pesta, dan tampil dalam pentas untuk pembacaan ayat suci Al Quran, rodat, dan pawai melantunkan tembang pujian kepada Tuhan. Panitia biasanya mengundang para elite desa baik dari kalangan kejawen dan santri, Girigondo, dan para tokoh santri di setiap dusun, tokoh partai politik PKB dan PPP di desa, pamong santri. Acara majemukan itu menjadi arena bagi komunitas santri untuk membangun jejaring sosial dan mempertahankan identitasnya sebagai komunitas yang kuat Islamnya.

Upacara majemukan kemudian menjadi model bagi elite santri untuk membangun berbagai pentas seni-budaya Islami di desa, seperti perayaan malam takbiran menyambut berakhirnya bulan suci Ramadan, lomba tilawatul Quran, perayaan haflah khotmil Quran dan Maulid Nabi, haul kyai Marzuki, peringatan hari jadi pondok pesantren, pergantian tahun baru Islam, dan lomba anak saleh. Dalam prosesi upacara Islami itu, para santri biasanya mengadakan upacara dan perayaan sebagai sebuah seni pertujukan yang mengundang banyak penonton. Dalam upacara itu, kyai pasti tampil sebagai pelindung, penceramah, pembawa doa, dan diiikuti dengan pentas seni rodat, pawai, dan selawatan.

Selama tahun 2015-2019, santri tidak mau ketinggalan dalam memajukan senibudayanya dibandingkan dengan kaum kejawen. Jika orang kejawen membuat berbagai acara kirab dan festival, santri telah mendahuluinya karena upacara majemukan diisi dengan acara serupa. Mereka juga telah mentradisikan bahwa tablik akbar menjelang hari raya Idul Fitri bukan lagi sekadar sebuah ritual, tetapi juga festival karena kaya dengan ekspresi pentas seni. Seorang informan mengatakan, "Dulu acara tablik akbar dipandang sebelah mata oleh anakanak kejawen, sekarang mereka suka nonton dan banyak yang ikut dan tiap tahun acara ini selalu menyedot perhatian warga".

Di pedukuhan Singosaren yang penduduknya terbagi hampir sama antara golongan kejawen dan santri, kaum santri selalu berusaha menyisipkan pentas seni Islami dalam penyelenggaraan upacara bersih dusun. Pada September 2019, misalnya, perayaan bersih dusun mementaskan wayang kulit, dan kirab budaya. Namun demikian, seminggu sebelumnya, Turmudi dan para ustaz menampilkan pentas seni rodat, dan pengajian akbar dengan mengundang kyai kondang di Bantul.

Komunitas santri juga berusaha mengembangkan festival yang Islami daripada festival ala kaum kejawen. Di Girigondo, misalnya festival anak saleh yang diadakan pada tangal 8 April 2018 . Festival ini memberikan penghargaan kepada kaum santri karena karakter mereka yang mengedepankan kesalehan dan keislaman dalam mendidik anak diapresiasi oleh komunitas dan publik di desa.

Dalam komunitas dusun, kaum santri juga membuat berbagai event publik sehingga tidak kalah dengan kaum kejawen. Event publik itu, misalnya membuka pasar hari minggu yang menjual produk-produk lokal. Di Dusun Cengkehan, misalnya warga santri membuat pasar di bawah hutan jati yang diramaikan dengan menjual produkproduk pakian islami, jamu, makanan tradisional dan diramaikan dengan pagelaran lagu-lagu Qosidah dan pop Islami.

Berbagai bentuk pengembangan senibudaya Islami di atas menunjukkan relevansinya bagi penguatan identitas santri. Kaum santri telah berhasil mengimbangi hegemoni kelompok kejawen dalam 
menguasai panggung kesenian di desa. Pengembangan seni-budaya Islami ini sebagai alat untuk memperkuat solidaritas internal, dan unjuk resistensi terhadap paham kejawen yang konotasinya masih lekat dengan sinkritisme agama.

\subsection{Relevansi Pengembangan Seni- Budaya dalam Pesta Demokrasi di Desa}

Bukan hanya memperkuat identitas dan solidaritas komunitas kejawen versus komunitas santri, pengembangan senibudaya berbasis pada politik aliran menjadi relevan bagi kepentingan elite untuk menjaga atau meningkatkan pengaruhnya di desa. Politik aliran memang masih tampak dalam pesta demokrasi di desa (Trihartono dan Patriadi, 2016). Selama tahun 2015-2019, sejumlah acara politik di desa sarat dengan hadirnya tokoh yang mempunyai kontribusi besar dalam pengembangan seni-budaya. Mereka mendapat apresiasi sebagai patron warga karena telah berjasa dalam penguatan identitas warga berbasis politik aliran

Acara politik di Pulungsari tahun 20152019 meliputi Pilkada Bantul 2015, Pilkades 2016, dan Pilkades 2018. Tiga acara politik itu memperlihatkan keterkaitan antara peran elite sebagai patron warga dalam memperkuat seni-budaya. Kontestan Pilkada 2015 adalah Harsono-Abdul yang diusung oleh Partai Gerindra dan PKB. Harsono berasal dari partai Gerindra sekaligus sebagai orang kejawen, sedangkan Abdul berasal dari PKB sekaligus sebagai orang santri. Mereka melawan Widati-Misbakhul dari pasangan PDIP dan Partai Nasdem masing-masing sebagai orang kejawen dan orang santri. Pemasangan kejawen dan santri sebagai upaya untuk merebut suara dari dua komunitas yang berbasis pada politik aliran.

Hasil Pilkada dimenangkan oleh Harsono-Abdul dengan perolehan suara 52, $8 \%$, sedangkan lawannya mendapatkan 47,2\%. Di Pulungsari, perolehan suara lebih tinggi, yaitu Harsono-Abdul meraih 4.820 suara $(54,4 \%)$, sedangkan Widati-Misbakhul meraih 4.099 suara $(45,6 \%)$.

Politik aliran di Pulungsari berpengaruh terhadap kecenderungan orang memberikan suara dalam pesta demokrasi dengan mengikuti pilihan kelompoknya yang disebut anut grubyuk (Sobari, 2018). Kemenangan sudah diduga akan diraih oleh pasangan Harsono-Abdul karena Abdul berasal dari Pulungsari. Selain itu, Abdul memang politisi PKB sehingga suara orang santri akan mengikuti tren kaum santri pada umumnya, sehingga tidak ada yang lari keluar ke Widadati-Misbakhul.

Politik aliran bekerja dalam arti, para elite desa santri memanfaatkan berbagai arena politik termasuk acara seni-budaya sebagai ajang sosialisasi dan kampanye terselubung untuk memperkenalkan dan memamerkan kehabatan dari pasangan Harsono-Abdul. Abdul sudah dikenal warga santri yang selalu aktif sebagai sponsor berbagai acara, seperti pengajian akbar, perayaan hari santri, ataupun haul Kyai Marzuki.

Sebaliknya, pasangan Widati-Misbakhul lebih banyak menggantungkan peran para elite kejawen. Meskipun elite kejawen dan komunitasnya merupakan mayoritas di desa, mereka terbelah menjadi dua kelompok, yaitu pro Harsono-Abdul dan pro WidatiMisbakhul. Hal ini karena Harsono mewakili Gerindra. Partai ini juga merepresentasikan orang kejawen. Kepala desa dan pamong cenderung memihak Widati-Misbakhul, tetapi mereka tidak bisa memobilisasi warga kejawen untuk memberikan suaranya hanya ke pasangan tersebut. Acara seni-budaya di komunitas kejawen juga tidak bisa dipakai sebagai ajang kampanye terselubung untuk mememangkan calon bupati. Kepala Desa Bayu mengatakan, "Saya tidak bisa masuk ke rumah warga, hadir di berbagai forum atau festival untuk mendukung kemenangan Widati-Misbakhul, karena saya selalu dibuntuti, diawasi, dan dicegah oleh tim 
sukses Harsono-Abdul". Dengan menekan gerak pamong untuk memenangkan WidatiMisbakhul, sebagian elite kejawen yang menjadi kader partai Gerindra berhasil memecah suara warga kejawen. Mereka juga memamerkan Harsono sebagai putra daerah yang kuat kejawennya seperti suka dengan wayang kulit dan ketoprak. Dengan demikian, pencalonan bupati pun dipakai komunitas untuk memperkuat identitas politik aliran. Sebaliknya, elite di daerah dan desa menggantungkan politik aliran untuk meraih suara dari konstituennya.

Memamerkan prestasi sebagai tokoh yang dekat dengan kaum kejawen dan santri juga relevan untuk mendapatkan suara dalam Pilkades. Persaingan politik dalam pilkades bersifat elitis (Aspinal dan Rohman, 2017). Mereka memanfaatkan politik aliran guna memenangkan kontestasi dan mendapatkan pengaruh di masyarakat (Subair, 2015).

Pada tanggal 23 Oktober 2017 berlangsung Pilkades untuk masa pemerintahan tahun 2017-2022. Pilkades ini diikuti lima orang dengan perolehan suara sebagai berikut: Wahyudi (1.756 suara), Turmudi (663 suara), Aminudin (2.136 Suara), Riyadi (292 suara), dan Bayu (4.964 suara). Pilkades dimenangkan oleh Bayu dengan memperoleh suara lebih dari 50\%.

Orang Pulungsari sudah bisa menebak bahwa pemenangnya adalah Bayu karena ia petahana yang memiliki rekam jejak yang baik dalam memajukan desa. Bayu bisa meraih suara banyak dari komunitas kejawen di seluruh wilayah Pulungsari, kecuali di Perdukuhan Pucung. Di Pucung, orang kejawen memilih jago kandangnya, yaitu Wahyudi dan Riyadi. Sementara itu, Aminudin yang basis suara pendukungnya berada di Perdukuhan Jimatan hanya mendapatkan suara sebanyak seperempat dari jumlah pemilih. Hal itu terjadi karena umumnya pemilih memberikan suara kepada petahana Bayu yang populer namanya.
Rekam jejak sebagai tokoh yang baik dan terkait dengan pengalaman memajukan desa, termasuk seni-budaya menjadi tiket penting untuk meraih suara pemilih dalam Pilkades. Semua calon, kecuali Aminudin belum berperan dalam memajukan desa.

Wahyudi berani maju menjadi calon karena dikenal sebagai tokoh pemuda yang aktif dalam berbagai acara seni-budaya dan kegiatan sosial di wilayah Pucung. Selain itu, kakaknya merupakan tokoh PDI yang selalu menjadi sponsor atas kegiatan sosial dan seni-budaya di tingkat perdukuhan atau pun desa.

Riyadi juga memiliki kontribusi yang besar dalam memajukan seni-budaya di Dusun Karangasem. Ia memiliki seperangkat gamelan untuk tempat warga Karangasem belajar seni karawitan dan pedalangan. Ia mendapatkan suara yang paling rendah dalam Pilkades. Sekalipun rendah, ia berhasil mendapat suara itu dari warga dusunnya karena mereka mengapresiasi atas kontribusinya dalam pelestarian seni-budaya Jawa.

Turmudi juga berani mencalonkan diri karena merasa mendapat dukungan kuat dari kalangan santri. Ia aktivis NU dan sekaligus juga pendiri panti asuhan di desanya. Ia sering memfasilitasi komunitas santri dalam menyelenggarakan berbagai acara senibudaya Islami di tingkat dusunnya maupun desa. Namun demikian, ia tidak bisa meraih suara dari seluruh warga santri. Diperkirakan oleh pengamat Pilkades di desa, ia hanya meriah kurang dari $25 \%$ suara santri, dan sisanya sebanyak $75 \%$ lebih diberikan untuk Bayu.

Bayu menang telak dengan berbagai rekam jejak yang baik selaku petahana. Salah satu rekam jejak bagus Bayu adalah menjadi pemimpin yang bisa memajukan seni-budaya Jawa di desa, seperti ikut mengembangkan festival kirab budaya Kecamatan Imogiri, membentuk perkumpulan karawitan, dan sering menyelenggarakan festival desa. 
Sementara itu, ia juga memajukan sentra ekonomi baik di komunitas kejawen, seperti sentra kerajinan kulit dan bambu di Pucung, perdagangan di Jimatan, dan batik di Girigondo. Nama Bayu harum di kalangan santri karena Bayu berhasil memberdayakan usaha batik tulis yang tidak lain kaum santri perempuan. Mereka merasa berhutang budi dan takut kalau kepala desa baru tidak sedekat mereka dengan Bayu. Oleh karena itu, mereka memilih Bayu daripada Turmudi yang santri tetapi dipastikan akan kalah karena tidak mempunyai dukungan politik yang luas di desa. Dengan demikian, kaum santri memiliki politik akomodatif untuk memenangkan pertarungan dengan menimbang kekuatan pemilihnya (Mukrimin, 2012).

Pada 2017 Bayu meninggal dunia sehingga 14 Oktober 2018 Desa Pulungsari menyelanggarkan Pilkades. Dalam Pilkades 2018, penggunaan politik aliran relevan untuk memenangkan persaingan.

Hasil perolehan suara sebagai berikut: Arohmad (401 suara); Harto (512 suara), Susilo (5.604 suara), Giyono (2.219 suara), dan Wahyudi (1.434 suara). Dengan demikian, pemenangnya adalah Susilo yang mendapatkan mendapatkan suara terbanyak, yaitu sebesar 5.604 suara.

Pilades 2018 dimenangkan oleh Susilo yang merupakan adik mantan kepala desa Bayu. Ia mewarisi rekam jejak baik dari Bayu yang sukses memimpin desa dan berhasil memajukan komunitas kejawen dan santri. Semua kompetitornya adalah orang kejawen, kecuali Giyono, yaitu seorang santri yang tinggal di komunitas kejawen. Giyono mendapat dukungan dari berbagai warga dari komunitas santri karena dikenal sebagai tokoh yang berhasil dalam membangun panti asuhan yatim-piatu dan menjadi sponsor festival budaya Islami di desa. Namun susah baginya merebut suara warga di Padukuhan Pucung karena warga cenderung memilik
Wahyu, mantan calon kepala desa Pilkades 2017 karena merupakan orang kejawen.

\section{Kesimpulan}

Artikel ini menggambarkan bahwa tesis politik aliran masih dapat dipakai untuk menggambarkan identitas komunitas kejawen versus santri Jawa pada masa Reformasi. Artikel ini menghasilkan temuan politik aliran menguat pada era reformasi karena menguatnya politik identitas dan identitas itu dibangun dengan mengembangkan senibudaya. Dengan demikian, orang kejawen mengembangkan identitas kejawaan sedangkan santri keislamannya.

Reformasi menjadi ajang terbuka dan bebas bagi warga dan elite untuk memperjuangan aspirasi politiknya. Oleh karena itu, baik kelompok kejawen maupun santri berlomba untuk memperkuat identitasnya dengan mengembangkan senibudaya bagi politik alirannya. Masingmasing kelompok membuat berbagai festival dan kirab budaya sehingga identitasnya menjadi tontotan yang populer di desa.

Artikel ini juga menunjukkan bahwa elite berperan aktif dalam pengembangan seni-budaya yang menjadi identitas bagi kelompok alirannya. Hal ini karena mereka akan mendapatan dukungan politik ketika berlaga dalam pesta demokrasi, seperti Pilkada dan Plikades. Dengan demikian, masuk akal kalau pengembangan senibudaya menjadi bagian penting bagi komunitas di desa yang terkungkung dalam politik aliran.

\section{Daftar Pustaka}

Antlöv, H. (2010). Village Government And Rural Development in Indonesia: The New Democratic Framework. Bulletin of Indonesian Economic Studies, 39(2), 193-214. https://doi.org/10.1080/000749103020 13

Arifin, A. (2008). Mengembangkan Islam Dengan Local Wisdom: Strategi Kebudayaan Nahdlatul Ulama. 
El_Harakah, 10(2), 135-145. https://doi.org/10.18860/el.v10i2.4583

Arinda R., \& Yani, I. (2014). Sedekah Bumi (Nyadran) sebagai Konvensi Tradisi Jawa dan Islam Masyarakat Sraturjo Bojonegoro. El Harakah, 16(1), 100110.

https://doi.org/10.18860/el.v16i1.2771

Aspinall, E., \& Rohman, N. (2017). Village head elections in Java: Money politics and brokerage in the remaking of Indonesia's rural elite. Journal of Southeast Asian Studies, 48(1), 31-52. https://doi.org/10.1017/S00224634160 00461

Baswedan, A. R. (2004). Political Islam in Indonesia: Present and Future Trajectory. Asian Survey, 44(5), 669690.

https://doi.org/10.1525/as.2004.44.5.6 69

Beatty, A. (2010). Varieties of Javanese Religion: An Anthropological Account. Cambridge: Cambridge University Pess. On Line Publication. https://doi.org/10.1017/CBO97805116 12497

Boogert, J. V. D. (2017). The Role of Slametan in the Discourse on Javanese Islam. Indonesia and Malay World, 45(133), 352-372. https://doi.org/10.1080/13639811.201 7.1345166

Burhani, A N. (2017). Geertz's Trichotomy of Abangan, Santri, and Priyayi Controversy and Continuity. Journal of Indonesian Islam, 11(2), 329-350. https://doi.org/10.15642/JIIS.2017.11. 2.329-350

Fauzi, M. L. (2012). Traditional Islam in Javanese Society, The Roles of Kyai and Pesantren in Preserving Islamic Tradition and Negotiating Modernity.
Journal of Indonesian Islam, 6(01), 125-144.

https://doi.org/10.15642/JIIS.2012.6.1. 125-144

Geertz. C. (2014). Agama Jawa, Abangan, Santri, Priyayi dalam Masyarakat Jawa. Jakarta: Komunits Bambu

Hilmy, M. (2018). Towards a Religiously Hybrid Identity? The Changing Face of Javanese Islam. Journal of Indonesian Islam, $\quad$ 12(1): 45-68. https://doi.org/10.15642/JIIS.2018.12. 1.45-68

Hudayana, B. (2011). Glembuk, Strategi Politik Elit dalam Rekrutmen Elit Penguasa di Desa Pulungsari Yogyakarta. Humaniora, 23(1), 1-13. https://doi.org/10.22146/jh.1005

Hudayana, B. (2015). Peranan Pemimpin dan Warga Desa Gumelem Wetan di Banjarnegara dalam Pelestarian SeniBudaya. Jantra, 10(1), 47-58

Irhandayaningsih, A. (2018). Pelestarian Kesenian Tradisional sebagai Upaya dalam Menumbuhkan Kecintaan Budaya Lokal di Masyarakat Jurang Blimbing Tembalang. ANUVA, 2 (1): 19-27.

http://ejournal.undip.ac.id/index.php/a nuva

Irianto, A.M. (2017). Kesenian Tradisional Sebagai Sarana Strategi Kebudayaan di Tengah Determinasi Teknologi Komunikasi. Nusa, 12. (1), 90-101

Jamil, M. M. (2013). Revitalisasi Islam Kultural. Walisongo: Jurnal Penelitian Sosial Keagamaan, 21(2), 271-308. https://doi.org/10.21580/ws.2013.21.2. 245

Junaidi, Suseno, B., \& Aziz A. (2018). Wayang untuk Dalang Multi Level Usia Sebagai Wahana Pelestarian Seni Tradisional, Jurnal Kajian Ilmu 
Budaya dan Perubahan Sosial, 2(1), 20-35.

http://ejournal.umm.ac.id/index.php/JI CC

Kholil, A (2011). Kebo-Keboan Dan Ider Bumi Suku Using: Potret Inklusivisme Islam di Masyarakat Using Banyuwangi. El Harakah, 13(2), 1-22. https://doi.org/10.18860/el.v0i0.1887

Kurtz, D. V. (2001). Political Anthropology, Power and Paradigms. Colorado: Westview

Masdar, H. (2018). Towards A Religiously Hybrid Identity? The Changing Face of Javanese Islam. Journal of Indonesian Islam, $\quad$ 12(1): 45-68. https://doi.org/10.15642/JIIS.2018.12. 1.45-68

Mufidah, Ch (2012). Pesantren Rakyat: Perhelatan Tradisi Kolaboratif Kaum Abangan Dengan Kaum Santri Pinggiran Desa Sumberpucung. El Harakah, 14(1), 115-134. doi: https://doi.org/10.18860/el.v0i0.2194

Mukodi \& Burhanuddin, A. (2016). Islam Abangan dan Nasionalisme Komunitas Samin di Blora. Walisongo: Jurnal Penelitian Sosial Keagamaan, 24(2), 379-400. doi: http://dx.doi.org/10.21580/ws.2016.24 .2 .1086

Mukrimin, M. (2012). Islamic Parties and The Politics of Constitutionalism in Indonesia. Journal Indonesian Islam, 06(02), 367-389. doi: https://doi.org/10.15642/JIIS.201 2.6.2.367-390

Nasif, H. dan Wilujeng, M. P. (2018). Wayang as Da'wah Medium of Islam According to Sunan Kalijaga. Kalimah: Jurnal Studi Agama-Agama dan Pemikiran Islam, 16(2), 261-268. doi: http://dx.doi.org/10.21111/klm.v1 6i2.2871
Riyadi, M. I., Mujahidin, A dan Tasrif, M (2016). Conflict And Harmony Between Islam and Local Culture dalam Reyog Ponorogo Art Preservation. El Harakah, 18(2), 145162.

doi: https://doi.org/10.18860/el.v18i2. 3498

Rubaidi, R. (2019). Java Islam: Relationship of Javanese Culture and Islamic Mysticism in the Post-Colonial Study Perspective. El Harakah, 21(1), 19-36. doi: https://doi.org/10.18860/el.v21i1. 6066

Schlehe, J (2017). Contesting Javanese Traditions: The Popularisation of Rituals between Religion and Tourism. Indonesia and the Malay World, 45(13), 3-23. doi: https://doi.org/10.1080/13639811.201 6.1219494

Sobari (2016). Anut Grubyuk in the Voting Process: The Neglected Explanation of Javanese Voters (Preliminary Findings). Southeast Asian Studies, 5(2), 239-268. doi: https://doi.org/10.20495/seas.5.2_ 239

Spradley. J. J. (2016). The Ethnographic Interview. Belmont: Wadsworth: Waveland Press

Subair. (2015). Abangan, Santri, Priyayi: Islam dan Politik Identitas Kebudayaan Jawa. Dialektika, 9(2), 34-46. doi: http://dx.doi.org/10.33477/dj.v9i2 .228

Suhardjono, L. A. (2016). Wayang Kulit and the Growth of Islam in Java. Humaniora, 7(2), 231-241. Doi: https://doi.org/10.21512/humanio ra.v7i2.3526

Surojo, S., \& Wicaksono, I.S. (2019). Peranan Seni Pertunjukan Barikan Qubro Dalam Mendukung Pariwisata 
Kepulauan Karimunjawa Kabupaten Jepara Jawa Tengah. Joged,13(1):4558.

doi: https://doi.org/10.24821/joged.v1 $3 \mathrm{i} 1.2806$

Tasrif, M. (2016). Conflict and Harmony between Islam and Local Culture in Reyog Ponorogo Art Preservation. ElHarakah, 18(2), 145-162. doi: 10.18860/el.v18i2.3498

Trihartono, A., \& Patriadi, H. B. (2016). The 2014 Indonesian General Election and Beyond: Melting "frozen" Cleavages. Asian Journal of Comparative Politics, 1(1), 25-43. doi: https://doi.org/10.1177/205789111562 0699

Triwardani, R., \& Rochayanti. C. (2014). Implementasi Kebijakan Desa Budaya Dalam Upaya Pelestarian Budaya Lokal. Reformasi, 4(2):102-11 